\title{
RECONNAISSANCE LIMNOLOGY OF TASMANIA VIII. TASMANIAN COASTAL LAGOONS - EPICENTRES OF ENDEMISM IN THE AUSTRALIAN AQUATIC MICROBIOTA
}

\author{
by R. G. J. Walsh, R. J. Shiel and P. A. Tyler
}

(with two text-figures, one plate and seven tables)

\begin{abstract}
Walsh, R. G. J., Shiel, R. J. \& TYLER, P. A., 2004 (29:x): Reconnaissance limnology of Tasmania VIII. Tasmanian coastal lagoons - epicentres of endemism in the Australian aquatic microbiota. Papers and Proceedings of the Royal Society of Tasmania 138: 67-76. https://doi.org/10.26749/rstpp.138.67 ISSN 0080-4703. Lower Basin Laboratory, Murray-Darling Freshwater Research Centre, PO Box 3428 Mildura, Victoria 3502, Australia (RGJW); School of Earth and Environmental Sciences, University of Adelaide, South Australia 5005, Australia (RJS); School of Ecology and Environment, Deakin University, PO Box 423, Warrnambool, Victoria 3280, Australia. ptyler@deakin.edu.au (PAT*) *Author for correspondence.
\end{abstract}

\begin{abstract}
Two clusters of coastal lagoons, one near Strahan on Tasmania's west coast, the other near St Helens on the north-east coast, are the prime known epicentres of novelty and endemism in the Australian freshwater algal flora. The algae inhabiting these acid, dystrophic lagoons have a very limited distribution. Other dystrophic lagoons may have one or two, but not all, of this suite of endemics. The Strahan dune lakes, especially Lake Garcia, also have the greatest microfaunal diversity yet recorded from any Tasmanian waterbody, including several endemic species. The St Helens sites are less rich in species of microfauna, perhaps because of climatic differences or perhaps because of less intensive sampling there, but they, too, contain endemic taxa. The lagoons in both areas lie outside the formal protection of national parks, but present land management does provide a measure of protection.
\end{abstract}

Key Words: coastal lagoons, dystrophic waters, algae, microfauna, endemism.

\section{INTRODUCTION}

Australiancoastallagoons, principally some in Tasmania, have been recognised as the strongholds of novel and uniquely Australian freshwater algae (Tyler 1992, 1996a). The results of a broad survey of Tasmanian coastal lagoons were presented earlier (Bowling et al. 1993, Walsh et al. 1995). With more taxonomicstudies (Croome et al. 1998) and recent field work in north-east Tasmania, and on islands of Bass Strait (Rolfe et al. 1999, Tyler 1996b, Walsh 1995, Walsh et al. 2001), it can now be said that the presently known epicentres of endemicity and novelty in the freshwater algal flora are clusters of lagoons near Strahan, western Tasmania, and at Stieglitz, near St Helens, north-eastern Tasmania. These same lagoons also contain endemic taxa of microfauna. Some, but not all, of the suite of endemics found in these two sets of lagoons occur in other lagoons dotted along the Tasmanian coastline, on islands in Bass Strait and on islands off the Queensland coast (Croome \& Tyler 1985, 1988, Croome et al. 1998, Ling et al. 1989, Tyler 1996a,b). Some physicochemical and limnological properties of some of the natural lagoons have been investigated by a number of authors and their unique or restricted algal flora and their microfauna have been reviewed (Bowling et al. 1993, Koste \& Shiel 1986, 1987, Shiel et al. 1989, Tyler 1996a, b, Walsh et al. 2001). This paper presents further detail on key lagoons on Tasmania's west coast, near Strahan, with two nearby, man-made lakes included for comparison, and at Stieglitz in the north-east of Tasmania.

\section{METHODS}

Geomorphological analyses of the lagoons were based on aerial photographs, topographical maps, ground photographs and field investigations. Sampling and analyses for chemical parameters were by the methods of Bowling et al. (1993). Plankton and littoral microfaunal samples were collected, and in situ measurements made, at three to five month intervals, between August 1991 and November 1994, from nine lagoons and two man-made lakes on Tasmania's west coast (fig. 1). The sampling effort for this period is indicated in Walsh (1996). Plankton and littoral microfauna also were collected from the west coast dune lakes during seven surveys for Tasmanian microfauna in the period 1984-97; methods and sampling effort for these surveys were consistent throughout, and are given in Koste \& Shiel (1986, 1987) and Shiel et al. (1989). The lagoons at Stieglitz were visited only occasionally, most intensively in February 1999. Microscopical observations were made in Strahan and St Helens and recorded by videomicroscopy. Collections are held by the authors. For deposition of type material refer to the taxonomic papers cited herein.

\section{RESULTS}

\section{Site Descriptions}

Table 1 gives brief details of the lagoons and reservoirs on the west coast included in this study. Those from St Helens are briefly described in the text. Photographs have been published previously of Lake Garcia, Lake Bantic and Hibb's Lagoon (Bowling et al. 1993, Croome \& Tyler 1988a) and of the three Stieglitz lagoons (Tyler 1996b). Preliminary data on some of the lagoons included here are given by Bowling et al. (1993) and Tyler (1996b). Parting Creek Dam, at Zeehan, and Lake Cumberland (pl. 1) are artificial reservoirs, each created, in the late 19th Century, simply by building a dam across a valley. The catchments of both are clothed in native western Tasmanian vegetation and water quality is essentially that of natural lagoons.

The natural lagoons of the west coast included in this study lie in sand dunes behind Ocean Beach, near Strahan (fig. 1), where there is a complex, vegetated, but eroding, 


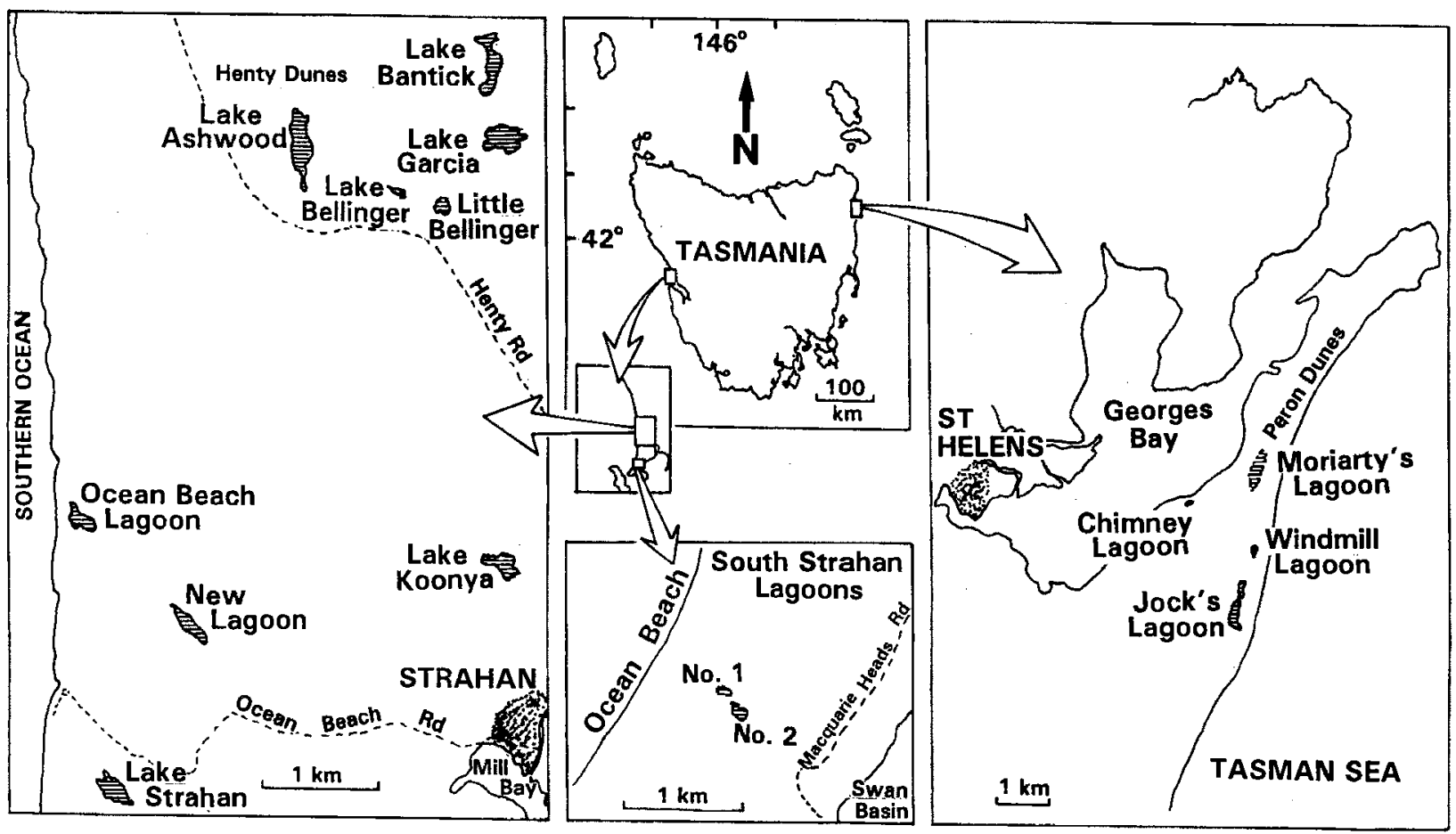

FIG. I- Map showing location of lagoons studied. The two reservoirs, Parting Creek Dam and Lake Cumberland (not shown), are accessed from Zeehan, $46 \mathrm{~km}$ north of Strahan.

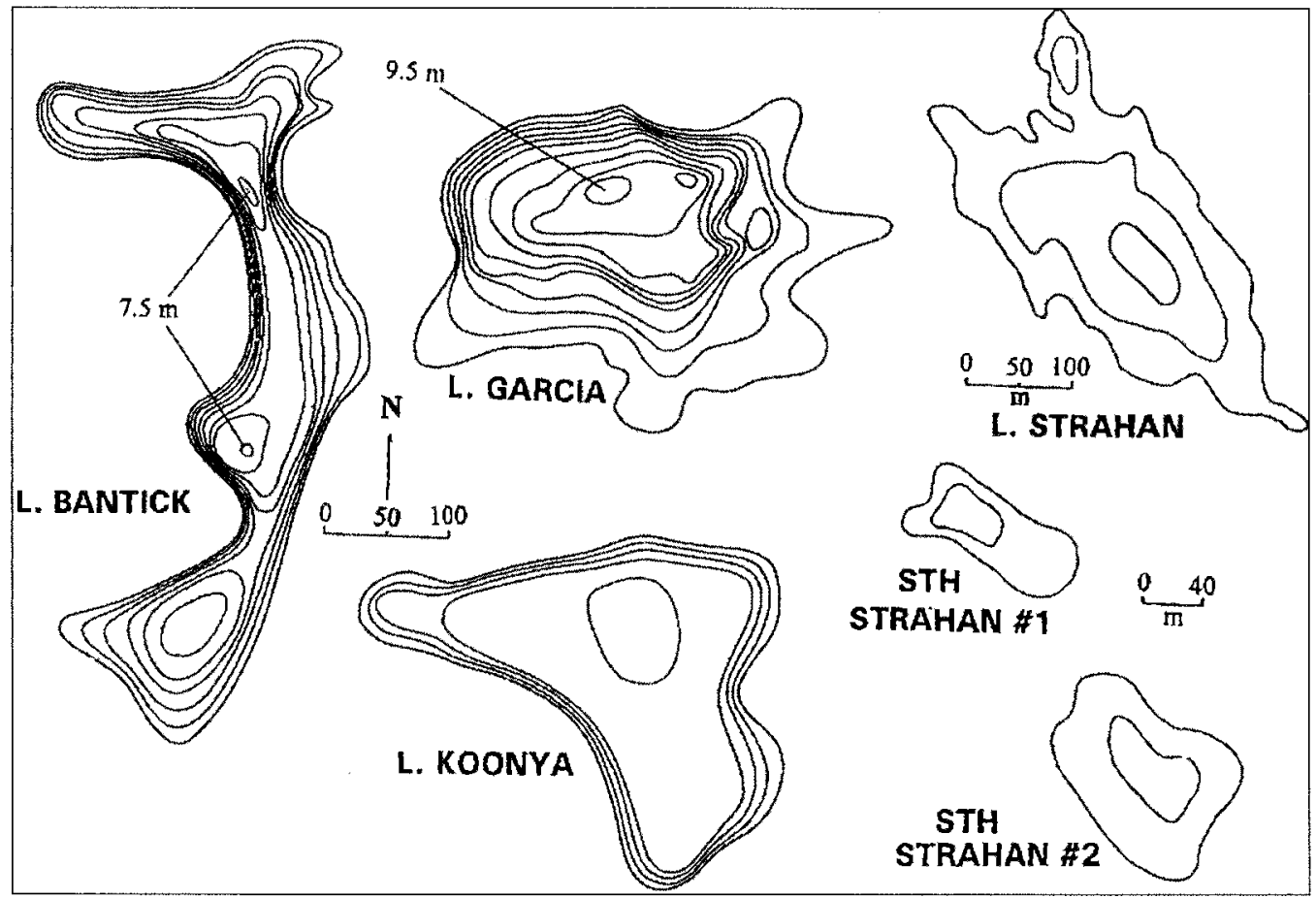

FIG. 2 - Bathymetric maps of selected coastal lagoons near Strahan. Contours are at $1 \mathrm{~m}$ intervals. 


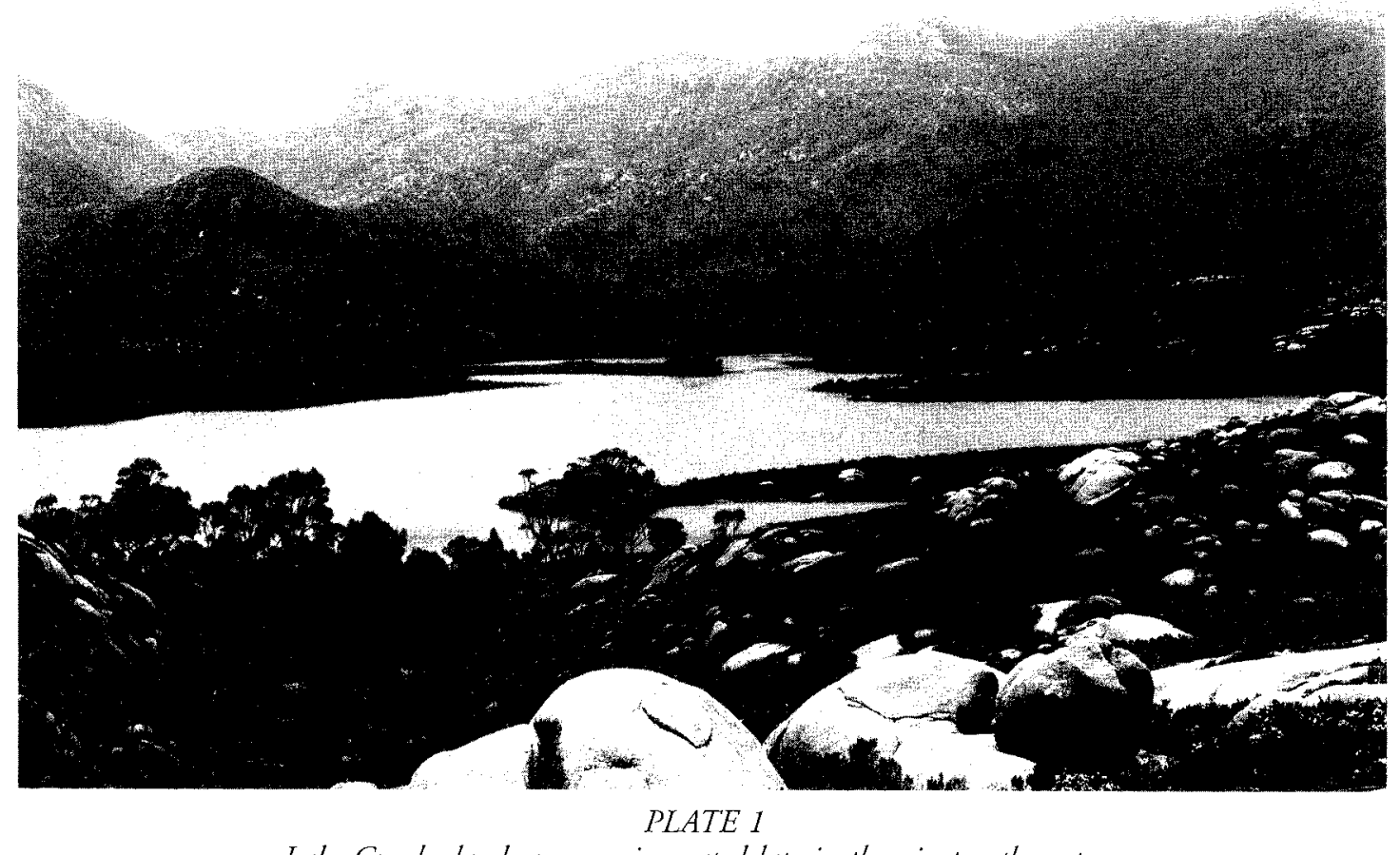

Lake Cumberland, a reservoir created late in the nineteenth century.

system of parabolic dunes of Pleistocene origin, extending up to $7 \mathrm{~km}$ inland. The source of sand for these dunes is believed to be siliceous, glacial and glaciofluvially derived sediments from the granitic lower gorge of the Little Henty and Henty Rivers (Banks et al. 1977). A number of Holocene, unvegetated, active and transgressive dunes occur immediately behind the beach, advancing inland at the rate of $17 \mathrm{~m}$ per year.

The source of sand for these dunes is the present Ocean Beach and blow-outs of the older Pleistocene dunes. Dunes just north of Strahan rise to $90 \mathrm{~m}$; vegetated dunes further inland reach a maximum of $147 \mathrm{~m}$ (Banks et al. 1977). There is a distinct contrast in the degree of soil development between unvegetated dunes and those, fully vegetated, inland. The progressive development, and increase in soil depth, with increasing distance inland, suggests a progressive increase in the age of dunes and this implies a source of sand different from the Henty River source of today. The age of dune building for Ocean Beach is thought to be similar to that in north-east Tasmania (Bowden 1978, 1983), King and Flinders Islands (Jennings 1959, 1961, Kershaw \& Sutherland 1972) and Bruny Island (Banks et al. 1977, Walsh et al. 1995). The area in which the west coast dunes lie experiences the strong winds of the Roaring Forties. The average annual rainfall is $1500 \mathrm{~mm}$, with an average of 240 rainy days per year.

Australian coastal lagoons have been classified by Timms $(1982,1992)$. The lagoons in the Strahan area are principally perched lakes (Timms' type i), lying on soils or organic mats developed within longitudinal or parabolic dunes. Hibbs Lagoon (Bowling et al. 1993, fig. 9) and Lake Koonya do not fit into Timms' classification. Their origins are indicated by Bowling et al. (1993).

The Stieglitz lagoons are located on a narrow peninsula, $10 \mathrm{~km}$ long, forming the southern shore of Georges Bay (fig. 1). The backbone of the peninsula is an outcrop of Devonian granite. Long shore drift has built up an extensive beach, with a single foredune, along much of this peninsula.
Between the foredune and the granite lie a number of freshwater lagoons and wetlands. In their geomorphology they are similar to those of Bruny Island (Walsh et al.1995). Photographs and preliminary data for these lagoons are given by Tyler (1996b).

Moriarty's Lagoon (fig. 1) is a shallow depression at the northern end of the granitic ridge, lying between it and the dunes to the north. In essence it is a swamp, heavily vegetated with Baumea, Juncus and other aquatic plants. It appears to be a combination of Timms' types ii and iv. In summer it dries up over most of its area.

Windmill Lagoon is located immediately behind the foredune, between it and the granite ridge. It is $4.5 \mathrm{~m}$ deep adjacent to the dune and has much of its area as open water. In addition there are stands of emergent Triglochin and Eleocharis in shallower areas. It is a Timms type iv lagoon.

Jocks Lagoon is similar in geomorphology to Windmill Lagoon but may have also some features of Timms' type ii. It is shallow $\left(\mathrm{z}_{\max }\right.$. ca. $\left.2.0 \mathrm{~m}\right)$, astatic and vegetated over most of its area.

\section{Morphometry and Physicochemical Attributes}

Available morphometric data are given in table 1. Bathymetric maps for some lagoons are shown in figure 2. Lake Strahan, South Strahan Lagoons and New Lagoon are astatic; the latter three may dry up in some years. Of the natural lagoons, only Hibbs Lagoon, Lake Mallana and Lake Koonya have inflow and outflow creeks. The morphological data show that the only natural lagoons likely to display seasonal stratification are Lake Garcia, Lake Bantic, Lake Mallana, Lake Koonya and Hibbs Lagoon.

Lake Garcia $\left(\mathrm{z}_{\text {max }} 9.5 \mathrm{~m}\right.$ ) is known to stratify (Bowling et al. 1993, fig. 10), with diminution in oxygen concentrations accompanying the thermocline. Additional measurements (unpublished) suggest that it stratifies in September and 
TABLE 1

Morphometry and brief description of coastal lagoons and reservoirs in the Strahan district, western Tasmania.

\begin{tabular}{|c|c|c|c|c|}
\hline Site & $Z \max m$ & $\begin{array}{c}\text { Surface area } \\
\text { (ha) }\end{array}$ & Description & Lake Type* \\
\hline Lake Garcia & 9.5 & & Holocene parabolic/longitudinal dune on siliceous sands. & Perched lagoon type i \\
\hline Lake Bantic & 7.5 & & Holocene parabolic/longitudinal dune on siliceous sands. & Perched lagoon type i \\
\hline Lake Strahan & 2.5 & 003.00 & Holocene parabolic/longitudinal dune on siliceous sands. & Perched lagoon type i \\
\hline New Lagoon & $<1.0$ & 001.00 & Holocene parabolic/longitudinal dune on siliceous sands. & Perched lagoon type i \\
\hline South Strahan No. 1 & 1.5 & 002.00 & Holocene parabolic/longitudinal dune on siliceous sands. & Perched lagoon type i \\
\hline South Strahan No. 2 & 1.5 & 001.00 & Holocene parabolic/longitudinal dune on siliceous sands. & Perched lagoon type i \\
\hline Lake Mallana & 4.5 & 001.00 & Tertiary sediments and Holocene siliceous dunes. & Dune contact type iv \\
\hline Lake Koonya & 4.5 & 002.00 & Tertiary sediments and Holocene siliceous dunes. & Slope change \\
\hline Hibbs Lagoon & 8.0 & & River valley and siliceous sands & $\begin{array}{l}\text { Natural impound- } \\
\text { ment }\end{array}$ \\
\hline Lake Cumberland & 4.0 & & Reservoir & Reservoir \\
\hline Parting Creek Dam & 5.5 & & Reservoir & Reservoir \\
\hline
\end{tabular}

* Lake type designated after Timms (1982).

turns over in May, giving approximately nine months of stratification. Despite this long period the lowest hypolimnetic oxygen concentration observed was about $5 \%$ of saturation value.

At the time of year when nearby lakes, such as Lake Garcia, are stratified, Lake Bantic may or may not be so (Bowling et al. 1993). The relatively long fetch of Lake Bantic (Bowling et al. 1993, figs 6,7) may prevent long lasting stratification in the windy climate of Tasmania's west coast. The thermal profile of Lake Mallana was not measured during this study, but it is known to stratify (Bowling et al. 1993). The suspected incipient meromixis of Hibbs Lagoon (Bowling et al. 1993) was confirmed by this study. Though only $4.0 \mathrm{~m}$ deep, Lake Koonya was thermally stratified on the one occasion examined. Another shallow lake in the vicinity, Little Bellinger, has also been observed to stratify (Bowling et al. 1993). Of the lagoons in the north-east, even the deepest, Windmill, is unlikely to stratify. Moriarty's Swamp is dry over much of its area in summer. Small pools of water remain in the lowest-lying parts of the swamp.

Some physical and chemical conditions of the lagoons and reservoirs studied are given in table 2 . The full, electronic database "STRAHLITZ" is available from the authors. The lagoons are all of moderate salinity (mostly $<500 \mu \mathrm{S} \mathrm{cm}^{-1}$ ). Ternary diagrams of major ions (not presented) confirm earlier data (Bowling et al. 1993) that ionic proportions are close to those of seawater.

The coastal lagoons and reservoirs of the west coast are, with the exception of Lake Bantic (see below), typically dystrophic. With $g_{440}$ values ranging from 3.0 to 59.1 , they rank as moderately to highly dystrophic on a Tasmania-wide scale (Bowling et al. 1986). This is the expected condition of "dim red window" (Tyler 1992) waters of western Tasmania. Euphotic depths determined quantaspectrometrically during this study ranged from $0.8-2.3 \mathrm{~m}$. Quantaspectroradiometric scans of Lake Strahan and others of comparable dystrophy reveal rapid attenuation of wavelengths less than about 500 $\mathrm{nm}$. At a depth of $0.5 \mathrm{~m}$ in such lakes wavelengths $<500-550$ $\mathrm{nm}$ are totally quenched (Bowling et al. 1986). As expected of dystrophic waters, $\mathrm{pH}$ values are low $(\mathrm{pH} 3.5-4.5)$.
An unexplained curiosity is that Lake Bantic, only $1 \mathrm{~km}$ from Lake Garcia (fig. 1), and surrounded by the same vegetation, is considerably less dystrophic than that lake and all neighbouring lagoons of this cluster. The reasons for this are not known but a pedological explanation is suspected. In keeping with the less dystrophic conditions the $\mathrm{pH}$ of Lake Bantic ( $\mathrm{pH} 4.8-5.8$ ) is a little higher than that of neighbouring dystrophic lagoons. Further data on the west coast lagoons are given by Walsh (1996).

Available physicochemical data for the north-east lagoons are given in table 2. Salinity values are higher that those of most west coast lagoons, especially for Moriarty's Swamp. Their $\mathrm{pH}$ values are also a little higher but their $\mathrm{g}_{440}$ values are comparable. Ionic proportions are close to those of seawater.

\section{Biological features}

Many of the natural west coast lagoons have emergent stands of aquatic macrophytes, either as fringing zones or patches in the shallows. Common species are Eleocharis sphacelata R. Br., Triglochin procera R. Br., Restio tetraphyllus Labill., Baumea sp. and Chorisandra sp. Sphagnum spp. also occur around some lagoons and Chara sp. covers the floor of the optically deep Lake Bantic.

The microinvertebrates found in west coast lagoons are listed in table 3. Typically, the planktonic microcrustacean community is monospecific, with the calanoid copepod Calamoecia tasmanica tasmanica (Smith) the usual dominant species. It is highly characteristic of dystrophic coastal lagoons throughout Tasmania (Walsh \& Tyler 1998). The exceptions to this are Lake Bantic, where the cladoceran Ceriodaphnia planifrons Smith occurred as subdominant, Parting Creek Dam, where the cladoceran Bosmina meridionalis Sars was subdominant, Lake Cumberland where $B$. meridionalis was the only planktonic crustacean and Lake Mallana where the cladoceran Daphnia sp. occurred on one occasion only.

Chydorid cladocerans ( $1-4$ spp.) occurred in the littoral zone of most lagoons, usually species of Alona, Alonella, Camptocercus, Chydorus, Graptoleberis or Rak. The genera 
TABLE 2

Summaty of some physicochemical conditions* of some lagoons and reservoirs on Tasmania's coast

\begin{tabular}{|c|c|c|c|c|}
\hline Lagoon & $\mathrm{pH}$ & $\mathrm{K}_{25}, \mathrm{~S} \mathrm{~cm}^{-1}$ & $\mathrm{~g} 440 \mathrm{~m}^{-1}$ & $Z_{\mathrm{cu}} \mathrm{m}$ \\
\hline L. Garcia & $4.3-5.6$ & $70-146$ & $3.2-10.4$ & $2.1-2.3$ \\
\hline L. Bantic & $4.8-5.9$ & $68-138$ & $0-0.9$ & $7.7-11.2$ \\
\hline L. Ashwood & $4.6-5.2$ & $127-152$ & $4.9-11.1$ & \\
\hline L. Koonya & $3.7-4.2$ & $107-122$ & $27.9-31.8$ & 1.2 \\
\hline L. Strahan & $4.2-5.1$ & $169-362$ & $6.9-50.5$ & $0.8-0.9$ \\
\hline L. Mallana & $3.5-4.2$ & $113-167$ & $15.1-27.5$ & 1.1 \\
\hline South Strahan Lagoons $1 \& 2$ & $3.5-4.0$ & $245-411$ & $25.2-59.1$ & \\
\hline New L. & $3.7-4.5$ & $176-212$ & $29.5-37.7$ & \\
\hline Ocean Beach L. & $4.6-4.7$ & $550-569$ & $13.9-14.3$ & \\
\hline L. Cumberland & $4.2-4.7$ & $48-73$ & $3.0-11.0$ & \\
\hline Hibbs L. & $6.1-6.8$ & $133-160$ & $4.4-10.8$ & 1.9 \\
\hline Parting Creek Dam & $4.1-5.9$ & $55-84$ & $5.7-16.1$ & 1.7 \\
\hline Jocks Lagoon & $4.6-4-9$ & $350-361$ & 22.0 & \\
\hline Windmill Lagoon & $5.9-6.2$ & $450-516$ & 5.3 & \\
\hline Moriarty Swamp & $6.1-6-9$ & $733-815$ & 16.1 & \\
\hline
\end{tabular}

* Data from the present study and from Bowling et al. 1993.

Ilyocryptus and Scapholeberis occurred amongst emergent macrophytes and Pseudomoina lemnae (King) was common in the astatic South Strahan Lagoons. A suite of cyclopoid copepods also occurred in the littoral of most lagoons, viz. species of Eu-, Macro-, Meso-, Micro-, Para-, Thermoor Tropocyclops, with an occasional record of primarily epibenthic or epiphytic canthocamptid harpacticoids, e.g., Canthocamptus sp. Ostracods were notably sparse, although the presence of occasional individuals of, e.g., Limnocythere in the littoral zone of some dune lakes indicates that some species may be present seasonally.

Preliminary studies of the rotifer fauna of the west coast lagoons showed them to be "unexpectedly rich in species" (Koste et al. 1988 p. 128) including many new records for Tasmania and two species new to science. On any visit, between 10 and 35 rotifer species were recorded in the zooplankton of any particular lagoon; rotifers were commonly the numerically dominant zooplankters, with the most common taxa being various species in the genera Conochilus, Keratella, Lecane, Polyarthra, Synchaeta and Trichocerca. Notably, on any given sampling day, each lagoon had a dominant taxon different from those of neighbouring lagoons. For example, in Lake Garcia dominant rotifers were Keratella cochlearis (Gosse) and Conochilus dossuarius (Hudson) while in Lake Ashwood, on the same day, dominants were Keratella javana Hauer and Conochilus hippocrepis (Schrank). Because of the vegetated nature of the sampling sites in each lagoon, rotifer assemblages invariably were a mixture of true plankters and littoral taxa. The lagoons also contain some species of rotifers endemic to Tasmania (table 6).

Also notable in collections from the west coast lagoons was a diverse array of testate Rhizopoda, a group poorly reported from Tasmania. Genera noted in the Strahan lagoons include Arcella, Centropyxis, Corythion, Cucurbitella, Difflugia, Euglypha, Hyalosphaenia, Lesquereusia and Trinema. Testate rhizopods have long been thought to be cosmopolitan, like the ciliated Protozoa (Finlay 1998, Finlay et al. 1996, 1999).
However, there is recent and increasing evidence that there is regionalism, if not endemism, in the Rhizopoda (Meisterfeld \& Tan 1998). The status of the poorly known Tasmanian testate amoebae remains to be investigated. A new species of the ciliated Protozoa (Ciliophora), Lembadion curvatum Esteban, Finley, Olma \& Tyler, 2000, was discovered recently in Lake Bantic (Esteban et al. 2000).

The considerable attention to date paid to the cluster of dystrophic lagoons on Tasmania's west coast has stemmed largely from the number of endemic or novel algae that live there. Tyler (1996a) recognises frail endemics with specific habitat preferences, met by the west coast lagoons and a few other places, and robust endemics that are more widely distributed and which tolerate a wider range of water conditions. A number of coastal lagoons dotted around the Tasmanian coast contain one or more frail endemics. The lagoons near Strahan, either collectively or singly, contain the full suite of frail endemic species described to date (table 5). Floristic and taxonomic studies are incomplete. Other new species are likely from these lagoons and certainly there are known species of chrysophytes and desmids not yet recorded from Australia but known to occur near Strahan and Sticglitz. A distinctive form of the desmid Pleurotaenium tridentulum Wolle G.S. West, with torsion of the corpus (Ling \& Tyler 2000), is known only from five lagoons: at Strahan (Lakes Garcia and Ashwood), Stieglitz (Jocks and Windmill Lagoon) and Millers Lagoon in southwest Tasmania.

The three lagoons near St Helens on Tasmania's northeast coast, have not been studied in detail, but their value as sites of diversity and endemism is proven (tables 6-7). The microcrustacean fauna (table 4) has been studied only briefly, but all three lagoons have as the dominant calanoid Calamoecia tasmanica tasmanica (Smith), a species which is highly characteristic of dystrophic lagoons (Walsh \& Tyler 1998). In keeping with the shallow, vegetated nature of the Stieglitz lagoons, the cladoceran assemblage is that of shallow waters, viz. the daphnids Ceriodaphnia and Simocephalus and a suite of chydorids from the genera Alona, Alonella, 
TABLE 3

Microinvertebrates and small macroinvertebrates from eight localities near Strahan on four dates

\begin{tabular}{|c|c|c|c|}
\hline Faunal group & No. taxa & No. genera & Genera/taxa \\
\hline Rhizopoda & 23 & 11 & $\begin{array}{l}\text { Arcella, Centropyxis, Corythion, Cucurbitella, Diffugia, Euglypha, Hyalosphaenia, Lesquereusia, } \\
\text { Pontigulasia Trinema, Zivkovicia }\end{array}$ \\
\hline Rotifera & 108 & 40 & $\begin{array}{l}\text { Bdelloidea indet., Rotaria, Anuraeopsis, Ascomorpha, Brachionus, Cephalodella, Collotheca, } \\
\text { Colurella, Conochilus Dicranophorus, Dipleuchlanis, Euchlanis, Filinia, Gastropus Hexarthra, } \\
\text { Keratella, Lecane, Lepadella, Lindia, Microcodon, Monommata, Notommata, Ploesoma, Polyarthra, } \\
\text { Pompholyx, Proales, Proalides, Proalinopsis, Resticula, Scaridium, Squatinella, Synchaeta, } \\
\text { Testudinella, Trichocerca, Trichotria, Tripleuchlanis }\end{array}$ \\
\hline
\end{tabular}

Cladocera $16 \quad 12$ Alona, Alonella, Camptocercus, Ceriodaphnia, Chydorus. Dunhevedia, Graptoleberis, Macrothrix, Pleuroxus, Rak, Scapholeberis, Simocephalus

\begin{tabular}{|c|c|c|c|}
\hline Copepoda & 8 & 7 & Calamoecia, Canthocamptus, Eucyclops, Macrocyclops, Mesocyclops, Paracyclops, Tropocyclops \\
\hline Ostracoda & 4 & 3 & Newnhamia, indet. genus/genera \\
\hline $\begin{array}{l}\text { Macroinverte- } \\
\text { brates }\end{array}$ & 10 & 10 & $\begin{array}{l}\text { Turbellaria: cf. Mesostoma; Oligochaeta: Naididae; Insecta: Collembola, Diptera: Chironomidae, } \\
\text { Coleoptera: Dytiscidae, Hemiptera: Notonectidae, Odonata: Zygoptera, Trichoptera; } \\
\text { Amphipoda; Acari Hydrachnidae/Oribatidae }\end{array}$ \\
\hline
\end{tabular}

TABLE 4

Microinvertebrates and small macroinvertebrates from four waterbodies at Stieglitz on four dates

\begin{tabular}{lccc}
\hline Faunal group & No.taxa & No. genera & \multicolumn{1}{c}{ Genera/taxa } \\
\hline Rhizopoda & 16 & 8 & Arcella, Centropyxis, Cucurbitella, Diffugia, Euglypha, Lesquereusia, Netzelia, Pontigulasia \\
Rotifera & 64 & 29 & $\begin{array}{l}\text { Bdelloidea indet., Ascomorpha, Brachionus, Cephalodella, Colurella, Conochilus, Dicranophorus, } \\
\text { Euchlanis, Filinia, Gastropus, Hexarthra, Keratella, Lecane, Lepadella, Macrochaetus, Monommata, } \\
\text { Mytilina, Notommata, Pompholyx, Ploesoma, Proales, Proalides, Resticula, Scaridium, Synchaeta, } \\
\text { Testudinella, Trichocerca, Trichotria, Tripleuchlanis }\end{array}$
\end{tabular}

Cladocera $\quad 16 \quad 12$ Alona, Alonella, Camptocercus, Ceriodaphnia, Chydorus, Dunhevedia, Graptoleberis, Macrothrix, Pleuroxus, Rak, Scapholeberis, Simocephalus

Copepoda 9 Boeckella, Calamoecia, Gladioferens, Eucyclops, Macrocyclops, Mesocyclops, Paracyclops,
Canthocamptus, Mesochra

Ostracoda 7 at least 4 Cypretta, Limnocythere, Newnhamia, indet. genus/genera

Macroinverte- $\quad 2 \quad 2 \quad$ Acari Hydrachnidae/Oribatidae

brates

Camptocercus, Chydorus, Graptoleberis and Pleuroxus. The Rotifera were comparably diverse, with most genera and many species, some of them Tasmanian endemic species (table 6), shared with the Strahan dune lakes. Of the three Stieglitz lagoons sampled, the greatest microfaunal diversity occurred in Jock's Lagoon (32 taxa).

As a group, the Stieglitz lagoons contain all the endemic algae found in the west coast lagoons (table 5). Floristic studies are incomplete but, as with the west coast lagoons, they are known to contain protistans not yet recorded for Australia and also probable new species. Windmill Lagoon and Moriarty's Swamp, in particular, are especially rich and diverse in desmids, chrysophytes and dinophytes. The Stieglitz lagoons also contain some Tasmanian endemics among the rotifers (table 7) and a chydorid crustacean, Alona rusticoides Smirnov \& Timms, endemic to Tasmania
(Smirnov \& Timms 1983). As with the west coast lagoons, those near Stieglitz are likely to harbour other species new to Tasmania, or new to science. They have been sampled at one time of year only, in summer, and on few occasions. Moriarty's Swamp, in particular, changes considerably with season, being inundated with water in winter but drying, or nearly so, in summer. Proper attention to seasonality would be highly likely to reveal more than this limited study has done.

\section{DISCUSSION}

Among the cluster of coastal lagoons near Strahan are some that are too shallow to stratify. Others, with depths in excess of about $4.0 \mathrm{~m}$, especially if sheltered from the prevailing 
westerly winds, do stratify. This is probably aided by the strong thermal gradients that develop in dystrophic lakes (Jones \& Arvola 1984, Bowling \& Salonen 1990). As an example, Lake Garcia stratifies early in the season and stratification persists until late, giving a stratified period of $8-9$ months. This is comparable to that for highly dystrophic and sheltered Lake Chisholm in northern Tasmania forests (Bowling \& Tyler 1988). In contrast, the limited numbers of measurements of clear-water Lake Bantic suggest a much shorter period. Rather surprisingly, while hypolimnetic oxygen concentrations do progressively decline in Lake Garcia, anoxia never occurs, despite the long period of stratification. Of the lagoons near St Helens, Moriarty's Swamp and Jocks Lagoon are too shallow to stratify and the limited data available suggest that the deeper Windmill Lagoon does not stratify either.

The physicochemical hallmark of the lagoons and reservoirs studied is low $\mathrm{pH}$, dystrophy, moderate salinity and seawater ionic proportions. This is usual for almost all surface waters of western Tasmania (Tyler 1992) and some coastal lagoons elsewhere. These conditions favour chromophytic phytoflagellates as dominants of the phytoplankton (Croome $\&$ Tyler 1987b) and the majority of the endemic algae are of this type (tables 5,7 ). The waters of the lagoons are strictly of the "dim red window" type (Bowling et al. 1986, Tyler 1992). Though the limited number of samples does not permit analysis of variability of physicochemical features, nothing in this study changes the earlier view (Bowling et al. 1993) that though there may be considerable variability it will not be sufficient to change the general limnological characters i.e., the lagoons will always be dystrophic and acid. This is probably significant for the maintenance of the characteristic populations of phytoflagellates and other organisms.

The west coast lagoons have a rich diversity of algae and rotifers, despite the view of Timms (1986) that rotifers are rare or absent from acidic dune lakes. A brief biogeography of Tasmanias Rotifera, given by Shiel et al. (1989), noted that the highest diversity and endemism was found to the west of the island, particularly around the Strahan dune lakes area. Lake Garcia, for example, remains the site of the highest rotifer species richness from a single collection in Tasmania (35 rotifer species). The endemic rotifers of the Strahan and Stieglitz lagoons are listed in table 6. In addition the west coast lagoons are the only known Australian sites for Euchlanis triquetra Ehrenberg and Testudinella ahlstromi Hauer. Eleven of Tasmania's 13 endemic rotifer species were previously thought to occur only in western dystrophic waters (Shiel et al. 1989). However, two of them have since been reported in acidic coastal or dune lakes elsewhere - Testudinella tasmaniensis Koste \& Shiel from SW Western Australia (Storey et al. 1993), and Lecane eylesi Russell (=L. tasmaniensis Shiel \& Koste) from the Chatham Islands (Russell 1953) and the west coast of the South Island of New Zealand (Shiel \& Green 1996). It is possible that more of the western Tasmanian endemics may be more widely distributed but, on present evidence, the western Tasmania rotifer species assemblage contains the highest proportion of indigenous taxa in any Australasian region.

In contrast to the richness of the rotifer communities of the dune lagoons, species diversity of microcrustacea is low. During this study only one species of calanoid copepod was present, though, previously (Walsh unpublished), Calamoecia australis (Searle) was recorded from Lake Garcia and Gladioferens spinosus Henry from Hibbs Lagoon. Cladoceran diversity also tended to be low and the Harpacticoida and Ostracoda were represented by only one or two species.
This is in contrast to the lagoons on the east and far northeast coasts of Tasmania (Walsh 1996), where there are typically 3-7 spp. present. This is attributed to differences in basin morphometry, complexity and cover of the aquatic macrophyte commmunity.

Considerable interest in the west coast lagoons centres on their harbouring endemic algae. The combinarion of low salinity, seawater ionic order, low $\mathrm{pH}$ and dystrophy appears to favour a small suite of species that are not found outside this sort of habitat. A further restriction is that the epicentre of this endemicity appears to be the coastal lagoons, not the remote montane lakes with apparently suitable water chemistry. These endemics have been called frail endemics, in contrast to those that apparently have more catholic tolerances and wider distributions (Tyler 1996a). While the lagoons near Strahan, and those near Stieglitz, are clearly the two strongholds, one or more species may occur in other dystrophic lagoons, dotted around Tasmania (Bowling et al. 1993, Tyler 1996a, Walsh et al. 1995), on the islands of Bass Strait (Walsh et al. 2001) and on islands off the Queensland coast (Croome et al. 1998). It is anticipated that frail endemic algae will only be found elsewhere outside Tasmania in waterbodies of this physicochemical nature, moreover only in complying waterbodies that also lie in native catchments or are surrounded by a buffer zone of such vegetation (cf. Walsh et al. 2001).

The occurrence of Prorocentrum foveolata Croome \& Tyler together with P. playfairi Croome \& Tyler in Moriarty Swamp is notable. $P$. playfairi is widely but sparsely distributed in Tasmania (Croome \& Tyler 1987a). It is found in dystrophic lagoons of low to moderate salinity with the exception of Bruny Island (Walsh et al. 1995), where salinities are higher. $P$. foveolata, on the other hand, has its stronghold on the mainland of Australia, with salinities considerably higher than the typical $P$ p playfairi habitats, and only a toehold in northeastern Tasmania (Tyler 1996b). The two species are known to coexist only in Moriarty's Swamp and in Reedy Lagoon on Flinders Island, Bass Strait (Walsh et al. 2001),

The presence of endemic algae, crustaceans and rotifers in these two groups of lagoons posed the question of what other protistan groups may also have endemic species there. In particular we wondered about the Ciliophora. It is widely believed that the ciliates are universally distributed (Finlay 1998, Finlay et al. 1996) but, we argued, that is an opinion based almost entirely on Northern Hemisphere experience. Surely, in the epicentres of Australian protistan novelty and endemism, we had the best chances of detecting endemism among the ciliates. A study carried out on mainland Australia, however, found that of 85 ciliate species in Tower Hill lakes, Victoria, all were previously known (Esteban et al. 2000, Finlay et al. 1999). Samples from the three St Helens lagoons and from Lake Bantic and Lake Garcia were examined. Only one new species, Lembadion curvatum, was found, in Lake Bantic (Esteban et al. 1999). However, the examinations were brief and cursory. The two clusters of lagoons in Tasmania are clearly prime sites in the debate about microbial biogeography and more detailed examination of their ciliate fauna is warranted.

Hibbs Lagoon was included in this study because of the interest of incipient meromixis rather than because of endemic algae. The two reservoirs were included because they demonstrate that frail endemics can colonise new waterbodies if water quality conditions are met (table 2). Because these two nineteenth century reservoirs were each 
TABLE 5

Occurrence of novel or endemic protists, referred to by the code given in Table 7 , in freshwater coastal lagoons and reservoirs of Tasmania.

\begin{tabular}{|c|c|c|c|c|c|c|c|}
\hline \multirow{2}{*}{$\frac{\text { Lagoon }}{\text { Lake Garcia }}$} & \multicolumn{7}{|c|}{ Protist } \\
\hline & $\mathrm{Du}$ & $\mathrm{Pp}$ & & $\mathrm{Pt}$ & Ss & $\mathrm{Tt}$ & Tv \\
\hline Lake Bantic & $\mathrm{Du}$ & $\mathrm{Pp}$ & Lc & $\mathrm{Pt}$ & Ss & $\mathrm{Tt}$ & \\
\hline Lake Ashwood & & & & $\mathrm{Pt}$ & & $\mathrm{Tt}$ & \\
\hline Lake Koonya & & & & & & $\mathrm{Tt}$ & \\
\hline Lake Strahan & $\mathrm{Du}$ & $\mathrm{Pp}$ & & $\mathrm{Pt}$ & Ss & $\mathrm{Tt}$ & $\mathrm{Tv}$ \\
\hline Lake Mallana & $\mathrm{Du}$ & $\mathrm{Pp}$ & & $\mathrm{Pt}$ & & $\mathrm{Tt}$ & \\
\hline Ocean Beach Lagoon & & & & & & $\mathrm{Tt}$ & \\
\hline Lake Cumberland & $\mathrm{Du}$ & & & & & $\mathrm{Tt}$ & \\
\hline Parting Creek Dam & $\mathrm{Du}$ & & & $\mathrm{Pt}$ & Ss & $\mathrm{Tt}$ & $\mathrm{Tv}$ \\
\hline Jocks Lagoon & & $\mathrm{Pp}$ & & $\mathrm{Pt}$ & Ss & $T t$ & \\
\hline Windmill Lagoon & $\mathrm{Du}$ & $\mathrm{Pp}$ & & & Ss & $T t$ & \\
\hline Moriarty Swamp & $\mathrm{Du}$ & $\mathrm{Pp}$ & Pf & & Ss & & \\
\hline
\end{tabular}

TABLE 6

Distribution of some microfauna, endemic to Australia, found in lagoons near Strahan and near St Helens (Stieglitz)

\begin{tabular}{lll}
\hline Species & Lagoon & Other localities \\
\hline Lecane sp. nov. (R) & Jocks & Tasmania (central plateau) \\
Notommata tyleri Koste, Shiel \& Tan (R) & Garcia & Dune lake, SW-Western Australia. \\
Testudinella tasmaniensis Koste \& Shiel (R) & Ashwood, Ocean Beach, Windmill. & western Tasmania \\
Testudinella unicornuta Koste \& Shiel (R) & Garcia, Strahan, Ashwood, Jocks. & western Tasmania \\
Trichotria buchneri Koste, Shiel \& Tan (R) & Garcia, Ashwood, Ocean Beach. & Tasmania \\
Alona misticoides Smirnov \& Timms (C) & Jocks, Windmill &
\end{tabular}

$\mathrm{R}=$ Rotifera, $\mathrm{C}=$ Cladocera

TABLE 7

Endemic or novel freshwater protist (algae unless otherwise indicated) found in one or more of the coastal lagoons or reservoirs on Tasmania's coast

\begin{tabular}{|c|c|c|c|}
\hline Species & Code & Reference & $\begin{array}{l}\text { Comments, } \\
\text { Distribution }\end{array}$ \\
\hline Prorocentrum playfairi & $\mathrm{Pp}$ & Croome \& Tyler $1987 \mathrm{a}$ & Tasmania and Bass Strait islands \\
\hline Prorocentrum foveolata & $\mathrm{Pf}$ & Croome \& Tyler $1987 \mathrm{a}$ & Mainland Australia, toehold in Tasmania \\
\hline Thecadiniopsis tasmanica & $\mathrm{Tt}$ & Croome et al. 1987 & Tasmania and Bass Strait islands \\
\hline Dinobryon unguentariforme & $\mathrm{Du}$ & Croome et al. 1988 & Tasmania, Queensland islands \\
\hline Tessellaria volvocina & Tv & Tyler et al. 1989 & Widespread in Australia \\
\hline Pleurotaenium tridentalum forma & $\mathrm{Pt}$ & Ling \& Tyler 2000 & Widespread in Tasmanian coastal lagoons \\
\hline Staurastrum sp. & Ss & $\begin{array}{l}\text { Undescribed. See King } \\
\& \text { Tyler } 1981 \text {, fig. } 6 \mathrm{~b}\end{array}$ & Widespread in Tasmanian coastal lagoons \\
\hline Lembadion curvatum Ciliophora & Lc & Esteban et al. 2000 & Only Lake Bantic \\
\hline
\end{tabular}


formed by damming a valley in the wilderness, conditions in the new waterbodies, once natural processes of decay of flooded vegetation had run their course, would be much as in a natural lake surrounded by native vegetation. Tyler (1996a) and Walsh et al. (2001) claim that this native water quality, or at least lack of arable or pastoral agriculture nearby, is the key criterion for survival of a population of frail endemics.

The lagoons near Strahan lie in Crown land but outside national parks. The cluster centred on Lake Garcia and the South Strahan Lagoons (fig. 1) lies in land under the management of Forestry Tasmania. Much of the land in the vicinity of the lagoons is used for coniferous plantations. Forestry Tasmania has been acquainted with the floristic values of lakes under their aegis. They have responded by declaring a $50 \mathrm{~m}$ buffer zone around all mapped lagoons and entering on Management Decision Classification maps additional Special Management Zones, where water quality must not be compromised by harvesting operations. Smaller ponds and rush grown pools will be considered also under the Forest Practices Code of Tasmania (Forestry Commission Tasmania 1994, R. A. Hamilton pers. comm.). Hibbs Lagoon lies outside the south-western World Heritage Area (Tyler 1992) but in the South West Conservation Zone. Lake Strahan, Lake Koonya and New Lagoon are managed by the Tasmanian Parks and Wildlife Service. This authority was made aware of the value of lagoons $>10$ years ago and is said (N. Ricketts pers. comm. 1998) to be pursuing protection measures; none is yet in place. The lagoons near Stieglitz lie on Crown land gazetted as a State Recreation Reserve. This affords some protection but, as in the vicinity of Strahan, there is community concern about the loss of recreational amenity if the lands are gazetted as a higher order of reserve.

This paper concludes a series concerned with a limnological reconnaissance of Tasmanian coastal lagoons. The island State boasts, in its remote, montane wilderness, a lakeland of unsurpassed beauty, diversity and limnological interest. Some of its attributes, especially the more glamorous, have been chronicled elsewhere (e.g., Tyler 1974, 1986, 1992, 1993, Tyler \& Wickham 1988, Tyler \& Vyverman 1995, Vyverman et al. 1995, Hodgson et al. 1997). This series has concentrated more on the aquatic biota of small, lowland lakes and coastal lagoons, places that are frequently passed by in favour of more attractive highland lakes, and frequently looked upon as places to be drained or filled in. But it is these rush-grown lagoons that are the epicentres of endemism and novelty in the microflora and microfauna. Proof of this endemism has been sought (Tyler 1992). It rests on the fact that frail endemics have been found in so few other places in Australia, despite widespread sampling (e.g., Croome \& Tyler 1985, 1988b, Ling \& Tyler 2000). Nonetheless, it is not possible to sample every lagoon in the continent and the occurrence of endemics in Queensland, and on stepping stones in Bass Strait (Rolfe et al., Walsh et al. 2001) indicates that a search elsewhere in Australia, in lagoons with appropriate water quality and with native vegetation surrounding them, could be fruitful. Areas that spring readily to mind are near Lismore, New South Wales, where Playfair (1915) recorded endemic algae, and in the south west of Western Australia, where Segers \& Shiel (2003) recorded endemic rotifers and Frey (1991) documented a suite of endemic chydorid cladocerans. It would be gratifying if novelty and uniqueness among the Australian aquatic microbiota were not largely a Tasmanian monopoly.

\section{ACKNOWLEDGEMENTS}

This study was financed by the Plomley Foundation, the National Estate Grants Programme (Project 9111), the University of Tasmania and Deakin University. We thank the National Parks and Wildlife officers in Strahan and the Landcare Group in St Helens for advice and assistance. The CSIRO Science Endowment Fund provided a dissecting microscope used for part of the microfauna survey. Dorothy Berner, Temple University, Philadelphia, is thanked for identifying the Lake Garcia/Lake Bantik Ceriodaphnia. We thank Carol Williams and Todd Dudley, both of St Helens, for valuable advice and liaison.

\section{BIBLIOGRAPHY}

BAnKS, M.R., ColHoun, E.A. \& CHICK, N.K., 1977: A reconnaissance of the geomorphology of central western Tasmania. In Banks, M. R. \& Kirkpatrick, J. B. (Eds): Landscape \& Man: The interactions between Man and environment in Western Tasmania. Royal Society of Tasmania, Hobart: 29-54.

BOWDEN, A.R., 1978: Geomorphic perspective on shallow ground water potential, coastal north-eastern Tasmania. Australian Water Resources Council, Technical Paper 36.

BOWDEN, A.R., 1983: Relict terrestrial dunes: Legacies of former climate in coastal north-east Tasmania. Zeitschrift für Geomorphologie N.F. 45: 153-174.

BOWLING, L.C. \& SALONEN, K., 1990: Heat uptake and resistance to mixing in small humic lakes and of forests in Southern Finland. Australian Journal of Marine and Freshwater Research 41: 747-755.

BOWLING, L.C. \& TYLER, P.A., 1988: Lake Chisholm, a polyhumic forest lake in Tasmania. Hydrobiologia 161: 55-67.

Bowling, L.C., STEAne, M.S. \& Trler, P.A., 1986: The spectral distribution and attenuation of underwater irradiance in Tasmanian inland waters. Freshwater Biology 16: 313-335.

Bowling, L.C., BANKS, M.R., CRoOMe, R.L. \& Tyler, P.A., 1993: Reconnaissance Limnology of Tasmania II. Limnological features of Tasmanian freshwater coastal lagoons. Archiv für Hydrobiologie 126: 385-403.

CroOME, R.L. \& TYler, P.A., 1985: Distribution of silica-scaled Chrysophyceae (Paraphysomonadaceae and Mallomonadaceac) in Australian inland waters. Australian Journal of Marine and Freshwater Research 36: 839-853.

CroOMe, R.L. \& TYLER, P.A., 1987a: Prorocentrum playfairi and Prorocentrum foveolata, two new dinoflagellates from Australian freshwaters. British Phycological Journal 22: $67-75$.

CroOme, R.L. \& Tyler, P.A., 1987b: Phytollagellates and their ecology in Tasmanian polyhumic lakes. Hydrobiololgia 161: 245-253.

Croome, R.L., Hallegraeff, G.M. \& TYler, P.A., 1987: Thecadiniopsis tasmanica gen. et sp. nov. (Dinophyta: Thecadiniaceae), a new peridinioid dinoflagellate from Tasmanian freshwaters. British Phycological Journal 22: 325-333.

CroOme, R.L., LING, H.U. \& TYLeR, P.A., 1988a: Dinobryon unguentariforme (Chrysophyceae), an unusual new species from Australia. British Phycological Journal 23: 129-133.

Croome, R.L. \& TYLeR, P.A., 1988b: Further observations of silica-scaled Chrysophyceae (Paraphysomonadaceae and Mallomonadaceae) from Australian freshwaters. Nova Hedwigia 46: 481-489.

CROOME, R.L., KRISTLANSEN, J. \& TYLER, P.A., 1998: A description of Mallomonas marsupialis (Synurophyceae) a new species from Australia with comments on the endemicity 
of Australian freshwater algae. Nordic Journal of Botany 18: 633-639

Esteban, G.F., Finlay, B.J., Olmo, J.L. \& TYler, P. A., 2000: Ciliated protozoa from a volcanic crater lake in Victoria, Australia. Journal of Natural History 34: 159-189.

FINLAY, B.J., 1998: The global diversity of protozoa and other small species. International Journal of Parasitology 28: 29-48.

FinLAY, B.J., EsTEBAN, G.F. \& FENCHEL, T., 1996: Global diversity and body size. Nature 383: 132-133.

Finlay, B.J., Esteban, G.F., Olmo, J.L. \& Tyler, P.A., 1999: Global distribution of free-living microbial species. Ecography 22: 138-144.

FrEY, D.G., 1991: The species of Pleuroxus and of three related genera (Cladocera, Chydoridae) in southern Australia and New Zealand. Records of the Australian Museum 43: 291-372.

Hodgson, D.A., TYLER P.A. \& Vyverman, W., 1996: The palaeolimnology of Lake Fidler, a meromictic lake in south west Tasmania and the significance of recent human impact. Journal of Paleolimnology 18: 313-333.

JENNINGS, J.N., 1959: The coastal geomorphology of King Island, Bass Strait, in relation to changes in relative level of land and sea. Records of the Queen Victoria Museum, Launceston 11: 1-39

JeNNINGS, J.N. 1961: Sea level changes in King Island, Bass Strait. Zeitschrift für Geomorphologie, Supplement 3: 80-84.

JONES, R.I. \& ARVOLA, L., 1984: Light penetration and some related characteristics in small forest lakes in Southern Finland. Internationale Vereinigung fir Theoretische und Angewandte Limnologie, Verbandlungen 22: 811-816.

KERSHAW, R.C. \& SUTHERLAND, F.L., 1972: Quaternary geomorphology of Flinders Island. Records of the Queen Victoria Museum, Launceston 43: 1-28.

KJnG, R.D. \& Tyler, P.A., 1981: Limnology of Perched Lake, south-west Tasmania. Australian Journal of Marine and Freshwater Research 32: 501-515.

KOSTE, W. \& SHIEL, R.J. 1986: New Rotifera (Aschelminthes) from Tasmania. Transactions of the Royal Society of South Australia 111: 93-109.

KOSTE, W. \& SHIEL, R.J., 1987: Tasmanian Rotifera: Affinities with the Australian fauna. Hydrobiologia 147: 31-443.

KOSTE, W., SHIEL, R.J. \& TAN, L.W., 1988: New rotifers (Rotifera) from Tasmania. Transactions of the Royal Society of South Australia 112: 119-131.

Ling, H.U., CroOme, R.L. \& TYler, P.A., 1989: Freshwater dinoflagellates of Tasmania, a taxonomic and ecological survey. British Phycological Journal 24: 111-129.

LING, H.U. \& TYLER, P.A., 2000: Australian freshwater algae (exclusive of diatoms). Bibliotheca Phycologia 105: 1-643, 159 pl. J. Cramer, Berlin and Stuttgart.

MEISTERFELD, R. \& TAN, L.W., 1998: First records of testate amoebae (Protozoa: Rhizopoda) from Mount Buffalo National Park, Victoria: preliminary notes. The Victorian Naturalist 115: 231-238.

PLAYFAIR, G.I., 1915: Freshwater algae of the Lismore District, with an appendix on the algal fungi and schizomycetes. Proceedings of the Linnean Society of New South Wales 40: 310-62.

Rolfe, S.F., KEW, P.L. \& TYLER, P.A., 2001: Reconnaissance limnology of Tasmania.VI. Physicochemical features of coastal lagoons of the Bass Strait islands. Archiv fur $\mathrm{Hyd}$ robiologie 150: 693-704.

RusSELL, C.R. 1953: Some Rotatoria of the Chatham Islands Records of the Canterbury Museum 6: 237-244.

SEgers, H. \& SHIEL, R.J., 2003: Microfaunal diversity in a biodiversity hotspot: new rotifers from south-western Australia. Zoological Studies 42: 516-521.

SHIEL, R.J. \& GREEN, J.D., 1996: Rotifera recorded from New Zealand, 1859-1995, with comments on zoogeography. New Zealand Journal of Zoology 23: 193-209

SHIEL, R.J., KOSTE, W. \& TAN, L.W., 1989: Tasmania revisited rotifer communities and habitat heterogeneity. Hydrobiologia 186/187: 239-245.

SMIRNOV, N.N. \& TIMMS, B.V., 1983: A revision of the Australian Cladocera (Crustacea). Records of the Australian Museum, Supplement 1: 1-132.

Storey, A.W., Halse, S.A. \& Shiel, R.J., 1993: The aquatic invertebrate fauna of the Two Peoples Bay area, southwestern Australia. Journal of the Royal Society of Western Australia 76: 25-32.

Timms, B.V., 1982: Coastal dune waterbodies of north eastern New South Wales. Australian Journal of Marine and Freshwater Research 33: 203-222.

Timms, B.V., 1986: The coastal dune lakes of Eastern Australia. In De Deckker, P. \& Williams, W. D. (Eds): Limnology in Australia. CSIRO, Melbourne \& W. Junk, Dordrecht: 421-432.

TIMMs, B.V., 1992: Lake Geomorphology. Gleneagles Publishing, Adelaide

TYLER, P. A., 1974: Limnological studies. In Williams, W.D. (Ed.): Biogeography and Ecology in Tasmania. Monographia Biologicae 25: 29-61. W. Junk, The Hague.

TYLER, P.A., 1986: Anthropological limnology in the Land of Moinee. In De Deckker, P. \& Williams, W. D. (Eds): Limnology in Australia. CSIRO, Melbourne \& W. Junk, Dordrecht: $532-537$.

TYLER, P.A., 1992: A Lakeland from the Dreamtime: The Second Founder's Lecture. British Phycological Journal 27: $353-368$

TYLER, P.A., 1996a: Endemism in freshwater algac. In Kristiansen, J. (Ed.) Biogeography of Freshwater Algae. Developments in Hydrobiology 118 (Hydrobiologia 336): 127-135.

TYLER, P.A., 1996b: The significance of north-east Tasmania for the biogeography of endemic Australian freshwater algae. Records of the Queen Victoria Museum, Launceston 103: 133-135.

TYleR, P.A. \& WICKHAM, R.P., 1988: Yan Yean revisited - a bicentennial window on Australian freshwater phycology. British Phycological Journal 23: 105-114.

TYLER, P.A. \& VYVERMAN, W.G., 1995: The microbial market place - trade-offs at the chemocline of meromictic lakes. Progress In Phycological Research 11: 325-370.

Tyler, P.A., PiPES, L., CroOME, R.L. \& LeEdALE, G.F., 1989: Tessellaria volvocina (Chrysophyca) rediscovered. British Phycological Journal 24: 329-337.

TYler, P.A., SHeRWOOD, J.E., MAGilton, C.J. \& Hodgson, D.A., 1996: Limnological and geomorphological considerations underlying Pedder 2000 - the campaign to restore Lake Pedder. Archiv für Hydrobiologie 136: 343 -361.

Vyverman, W., Vyverman, R., HOdGSON, D. \& Tyler, P.A., 1995: Diatoms from Tasmanian mountain lakes: a reference data set (TASDIAT) for environmental reconstruction and a systematic and autecological study. Bibliotheca Diatomologica 33: 1-193, $42 \mathrm{pl}$.

WALSH, R.G.J., 1996: Limnology of Tasmanian freshwater coastal dune lakes with particular reference to the microcrustacea. Unpubl. PhD thesis, University of Tasmania, Hobart.

Walsh, R.G.J., VyVerman, W.G. \& TYLER, P.A., 1995: Reconnaissance limnology of Tasmania III. Coastal lagoons of Bruny Island. Archiv für Hydrobiologie 136: 247-260.

WALSH, R.G.J. \& TYLER, P.A., 1998: Reconnaissance limnology of Tasmania IV. The distribution and ecological preferences of Tasmanian species of freshwater calanoid copepods (Crustacea: Centropagidae). Archiv für Hydrobiologie 141: 403-420.

WALSH, R.G.J., SHIEL, R.J. \& TYLER, P.A., 2001: Reconnaissance limnology of Tasmania VII. Coastal lagoons of Bass Strait islands, with reference to endemic microflora and microfauna. Archiv fïr Hydrobiologie 152: 489-510.

(accepted 2 August 2004) 